\title{
Penampilan 15 Genotipe Kedelai Hitam (Glycine soja(L.) Merr) pada Pertanaman Tumpangsari 2:1 dengan Jagung
}

\author{
M. Khais Prayoga ${ }^{1}$, Meddy Rachmadi ${ }^{2}$, dan Noladhi Wicaksana ${ }^{2}$ \\ ${ }^{1}$ Alumni Program Studi Agronomi, Fakultas Pertanian, Universitas Padjadjaran \\ ${ }^{2}$ Program Studi Agronomi, Fakultas Pertanian, Universitas Padjadjaran \\ Jl. Raya Bandung-Sumedang KM 21 Jatinangor 40600 \\ *Alamat korespondensi: mkhaisprayoga@yahoo.com
}

\begin{abstract}
Yield Characters of 15 Black Soybean Genotypes (Glycine soja (L.) Merr) in Intercroping Pattern of 2:1 with Corn
\end{abstract}

The purpose of this study was to determine the character of 15 black soybean genotypes in intercroping pattern 2:1 with corn. This study used experimental methods based on Randomized Block Design (RBD) with 15 black soybean genotypes that repeated twice. The experiment arranges in 2:1 cropping (two rows soybean and one row corn). The observations were made to the character's yield of the number of pods per plant, the number of seeds per plant, weight of 100 seeds, weight of seeds per plant, and weight of seeds per row. The result showed that the genotypes that better than Cikuray and Malika cultivars were BTN 1, BTN 2, BTN 5 and CK 5 in the number of seeds per plant, genotype CK 5 in the number of pods per plant, genotype SM 2 in the number of pods and seeds per plant. Furthermore, genotypes CK 0, KA 6 and KA 7 in the number of pods and seeds per plant and weight of seeds per row.

Keywords: Black soybean, Intercroping, Yield

\begin{abstract}
ABSTRAK
Peningkatan minat petani untuk menanam kedelai dapat dilakukan melalui sistem tanam tumpangsari kedelai dengan jagung untuk mengurangi kemungkinan kerugian akibat gagal panen. Tujuan dari penelitian ini adalah untuk mengetahui bagimana penampilan karakter daya hasil 15 genotipe kedelai hitam pada pertanaman tumpangsari pola 2:1 dengan jagung. Penelitian ini menggunakan metode eksperimen berdasarkan Rancangan Acak Kelompok (RAK) dengan 15 genotip kedelai hitam sebagai perlakuan yang diulang sebanyak dua kali. Percobaan disusun dalam pertanaman 2:1 (dua baris kedelai dan satu baris jagung). Pengamatan dilakukan terhadap karakter daya hasil yaitu jumlah polong per tanaman, jumlah biji per tanaman, bobot 100 biji, bobot biji per tanaman, dan bobot biji per baris. Hasil penelitian menunjukkan bahwa genotipe-genotipe yang lebih unggul dibandingkan dengan kultivar Cikuray dan Malika adalah BTN 1, BTN 2, BTN 5, dan CK 5 pada karakter jumlah biji per tanaman, genotipe CK 15 pada karakter jumlah polong per tanaman, genotipe SM 2 pada karakter jumlah polong per tanaman dan jumlah biji per tanaman, serta genotipe CK 0, KA 6, dan KA 7 pada karakter jumlah polong per tanaman, jumlah biji per tanaman dan bobot biji per baris.
\end{abstract}

Kata Kunci: Kedelai hitam, Tumpangsari, Daya hasil

\section{PENDAHULUAN}

Kebutuhan kedelai di Indonesia setiap tahun selalu meningkat seiring dengan pertambahan penduduk dan peningkatan pendapatan perkapita. Kebutuhan total kedelai nasional per tahun mencapai 2,2 juta ton, sedangkan kapasitas produksi nasional hanya 700-800 ribu ton. Kekurangan 
kebutuhan nasional ditanggulangi dengan melakukan impor (Pusat Data dan Sistem Informasi Pertanian, 2015). Setelah keran impor kedelai dibuka, tidak ada lagi pengendalian atau proteksi sehingga harga kedelai lokal menjadi rendah. Hal tersebut membuat petani tidak berkeinginan untuk menanam kedelai sehingga peningkatan produksi nasional semakin sulit. Upaya yang dilakukan dalam meningkatkan minat petani untuk menanam kedelai adalah melalui sistem tanam tumpangsari kedelai dengan jagung. Sistem tumpangsari kedelai dengan jagung mengurangi kemungkinan kerugian akibat gagal panen (Rifai dkk., 2014) maupun gejolak harga yang tidak menentu. Selain itu, tujuan dari sistem tumpang sari kedelai dengan jagung adalah efisiensi dalam pemanfaatan waktu, ruang dan sumberdaya alam yang tersedia sehingga produksi usaha tani menjadi maksimal (Beets, 1982).

Pada pertanaman tumpangsari kedelai dan jagung perbedaan morfologi antara kedua tanaman itu menyebabkan terjadinya kompetisi baik itu penyerapan unsur hara dalam tanah, udara, dan penyerapan cahaya. Pola pertanaman tumpangsari kedelai dengan jagung yang biasa digunakan petani adalah 3:1, 4:1 dan 5:1. Pada ketiga pola tersebut, jika dilihat dari aspek cekaman tidak semua genotipe kedelai berinteraksi langsung dengan jagung sehingga cekaman yang dialami oleh kedelai yang berinteraksi dengan jagung akan berbeda dengan cekaman yang dialami kedelai yang berinteraksi dengan kedelai. Hal tersebut dapat memberikan hasil penelitian yang bias (Rachmadi, 2002).

Pola pertanaman 2:1 merupakan modifikasi dari ketiga pola tumpangsari yang biasa digunakan. Pola tumpangsari 2:1 memungkinkan seluruh komponen tanaman kedelai memperoleh pengaruh kompetisi antar spesies yang sama. Pada tumpangsari 1:1 tanaman kedelai juga akan memperoleh kompetisi antar spesies yang sama, namun pada tumpangsari 1:1 kondisi cekaman terlalu tinggi sehingga potensi genetik karakter kedelai tidak terekspresi sepenuhnya (Rachmadi, 2002).

Saat ini Laboratorium Pemuliaan Tanaman, Fakultas Pertanian, Universitas Padjadjaran telah mengoleksi 13 genotipe kedelai hitam yaitu BTN 1, BTN 2, BTN 5, CK 0, CK 5, CK 6, CK 15, JT 3, KA 6, KA 7, KBI 2, KH 8, dan SM 2 yang diharapkan toleran atau adaptif pada pola pertanaman tumpangsari dengan jagung. Untuk mengetahui genotipe kedelai unggul pada pola tanam tumpangsari perlu diketahui bagimana penampilan karakter daya hasil kedelai pada pertanaman tumpangsari 2:1.

\section{BAHAN DAN METODE}

Penelitian dilaksanakan di Kebun Percobaan Ciparanje, Fakultas Pertanian, Universitas Padjadjaran yang berlokasi di Kecamatan Jatinangor, Kabupaten Sumedang, Jawa Barat. Penelitian ini menggunakan metode eksperimen berdasarkan Rancangan Acak Kelompok (RAK) dengan 15 genotip kedelai sebagai perlakuan yang diulang dua kali. Lima belas genotipe itu terdiri atas 13 genotipe yang diuji dan tiga genotipe sebagai kultivar cek. Kultivar cek yang dipergunkan adalah Arjasari, Cikuray dan Malika. Percobaan disusun dalam pertanaman 2:1 (dua baris kedelai dan satu baris jagung). Pengamatan dilakukan terhadap karakter daya hasil yaitu, jumlah polong per tanaman, jumlah biji per tanaman, bobot 100 biji, bobot biji per tanaman, dan bobot biji per baris.

Analisis varian dilakukan untuk mengetahui perbedaan respon masing-masing genotip terhadap lingkungan. Analisis gabungan yang digunakan adalah model analisis Eberhart \& Rushell yang telah dideskripsikan oleh Singh \& Chaudhary (1977) sebagai berikut:

$\mathrm{Y}_{\mathrm{ijr}}=\mu+\mathrm{g}_{\mathrm{i}}+\mathrm{l}_{\mathrm{j}}+(\mathrm{gl})_{\mathrm{ij}}+\varepsilon_{\mathrm{ijr}}$

Keterangan:

$\mathrm{Y}_{\mathrm{ijr}}=$ Hasil pengamatan dari genotip ke i, lingkungan ke $\mathrm{j}$, dan ulangan ke $\mathrm{r}$

$\mu=$ Nilai tengah rata-rata umum

$\mathrm{g}_{\mathrm{i}} \quad=$ Pengaruh genotip ke-i

$l_{j} \quad=$ Pengaruh lingkungan ke- $j$

$(\mathrm{gl})_{\mathrm{ij}}=$ Pengaruh interaksi genotip ke i dan lingkungan ke-j

$\varepsilon_{\mathrm{ijr}}=$ Pengaruh galat percobaan

Tabel analisis varians gabungan menurut Gomez \& Gomez (1995) berdasarkan model linear yang dijelaskan sebelumnya adalah sebagai berikut:

Tabel 1. Analisis varian Rancangan Acak Kelompok untuk tumpangsari 2:1.

\begin{tabular}{lccl}
\hline Sumber varians & $\mathrm{Db}$ & $\mathrm{KT}$ & $\mathrm{KTH}$ \\
\hline Ulangan & $\mathrm{r}-1$ & & \\
Genotip & $\mathrm{g}-1$ & $\mathrm{M}_{2}$ & $\sigma^{2} \mathrm{e}+\mathrm{r}^{2} \mathrm{~g}$ \\
Galat & $(\mathrm{r}-1)(\mathrm{g}-1)$ & $\mathrm{M}_{3}$ & $\sigma^{2} \mathrm{e}$ \\
Total & $\mathrm{rt}-1$ & $\mathrm{M}_{1}$ & \\
\hline
\end{tabular}

Menurut Petersen (1994), untuk menilai tingkat ketelitian pada setiap tipe pertanaman 
dianalisis nilai koefisien variasi (KV). Adapun rumusnya adalah sebagai berikut:

$K V=\left(\frac{\sqrt{M_{3}}}{\dot{y}}\right) \times 100 \%$

Keterangan:

$\mathrm{M}_{3} \quad=$ kuadrat tengah galat

Ý $\quad=$ rata-rata genotip

Untuk menentukan genotip yang mempunyai hasil lebih baik dari pada genotip cek maka dilakukan uji Least Significant Increase (Petersen, 1994) sebagai berikut:

$L S I=t_{\mathrm{\alpha c}} \sqrt{\frac{2 M_{3}}{r}}$

Keterangan:

$\mathrm{t}_{\alpha}=$ nilai tabel pada taraf $5 \%$

$\mathrm{M}_{3}=$ nilai kuadrat tengah galat

$\mathrm{r}$ = ulangan

Setelah diperoleh nilai LSI, kemudian dihitung nilai LSI $+\mathbf{x}$, dimana $\mathbf{x}$ adalah nilai rata-rata kultivar cek. Selanjutnya nilai rata-rata genotipe yang diuji per karakter dibandingkan dengan nilai LSI + x. Nilai to pada rumus LSI adalah nilai taraf uji kepercayaan 5\%.

\section{HASIL DAN PEMBAHASAN}

Kegiatan seleksi pada penelitian ini diarahkan untuk memperoleh genotipe yang lebih baik dari kultivar cek (Arjasari, Cikuray, dan Malika) pada pola tanam tumpangsari 2:1. Genotipe-genotipe yang lebih baik dari kultivar cek diasumsikan memiliki potensi hasil yang tinggi karena kultivarkultivar cek yang diperguanakan merupakan kultivar berdayahasil tinggi dan telah dilepas oleh Kementerian Pertanian Republik Indonesia serta telah banyak dibudidayakan oleh petani kedelai. Hasil analisis sidik ragam menunjukkan semua karakter hasil kedelai pada tumpangsari 2:1 berbeda nyata pada taraf $5 \%$ dan $1 \%$. Karakter jumlah polong per tanaman dan bobot 100 biji berbeda sangat nyata pada taraf $1 \%$, sedangkan karakter lain berbedanyata pada taraf 5\%. Hasil tersebut menunjukkan terdapat variasi antar genotipe-genotipe yang diuji. Nilai Koevisien Variasi berkiasar anatara 6,61\%-15,92\% (Tabel 2). Nilai KV menunjukkan tingkat ketepatan dari perlakuan yang diperbandingkan dan merupakan indeks yang baik dari keadaann penelitian (Gomez \& Gomez, 1995). Menurut Gasperz (2006), nilai KV yang tidak lebih dari 20\% adalah baik, artinya galat percobaan untuk karakter- karakter tersebut relatif kecil. Dengan demikian tingkat ketepatan dalam penelitian ini adalah baik.

Tabel 2. Sidik ragam karakter daya hasil kedelai pada tumpangsari 2:1.

\begin{tabular}{lcc}
\hline \multicolumn{1}{c}{ Karakter } & Genotipe & KV (\%) \\
\hline $\begin{array}{l}\text { Jumlah polong per } \\
\text { tanaman }\end{array}$ & $4,86^{* *}$ & 12,17 \\
$\begin{array}{l}\text { Jumlah biji per } \\
\text { tanaman }\end{array}$ & $2,86^{*}$ & 15,92 \\
$\begin{array}{l}\text { Jumlah buku subur } \\
\text { per tanaman }\end{array}$ & $2,44^{*}$ & 6,61 \\
$\begin{array}{l}\text { Bobot } 100 \text { biji } \\
\text { Bobot biji per }\end{array}$ & $23,55^{* *}$ & 7,1 \\
$\begin{array}{l}\text { tanaman } \\
\text { Bobot biji per baris }\end{array}$ & $2,96^{*}$ & 11,55 \\
\hline $\begin{array}{l}\text { Keterangan: }{ }^{*} \text { = berbedanyata pada taraf } 5 \%,{ }^{* *}=\text { berbeda nyata } \\
\text { pada taraf } 1 \% \text {, tn = tidak berbeda nyata. }\end{array}$
\end{tabular}

Untuk melihat genotipe-genotipe mana saja yang memiliki penampilan lebih baik dibanding kultivar cek (Cikuray dan Malika) untuk karakter hasil pada tumpangsari 2:1 dilakukan uji lanjut LSI (Tabel 3). Hasil uji lanjut menunjukkan terdapat genotipe-genotip yang lebih unggul dibanding kultivar Cikuray dan Malika. Pada karakter jumlah polong per tanaman genotipe CK $0(20,08)$, CK 15 $(17,60)$, CK $6(17,00)$, JT $3(20,33)$, KA $6(20,83)$, dan KA $7(19,30)$ lebih baik dari kedua kultivar cek. Sementara itu, genotipe-genotipe lain hanya lebih baik dibanding dengan kultivar Cikuray.

Pada karakter jumlah biji per tanaman terdapat 10 genotipe yang lebih baik dari kedua kultivar cek. Pada karakter itu terdapat genotipe yang memiliki jumlah polong per tanaman sedikit namun memiliki jumlah biji per tanaman yang banyak, begitu pula sebaliknya. Genotipe BTN 1, BTN 2, BTN 3, dan CK 5 pada karakter jumlah polong per tanaman hanya lebih baik dibandingkan dengan kultivar Cikuray, akan tetapi pada karakter jumlah biji per tanaman keempat genotipe tersebut lebih baik dari kultivar Cikuray dan Malika. Genotipe CK 15 yang memiliki jumlah polong per tanaman lebih banyak dibandingkan dengan kultivar Cikuray dan Malika tidak lebih baik pada karakter jumlah biji per tanaman. Hal tersebut diduga akibat cekaman yang dialami oleh masing-masing genotipe pada pertanaman tumpangsari 2:1. 
Tabel 3. Hasil uji LSI karakter hasil 13 genotipe kedelai pada tumpangsari 2:1.

\begin{tabular}{lccccc}
\hline \multirow{2}{*}{ Genotipe } & \multicolumn{5}{c}{ Karakter } \\
\cline { 2 - 6 } & $\begin{array}{c}\text { Jumlah polong } \\
\text { per tanaman }\end{array}$ & $\begin{array}{c}\text { Jumlah biji } \\
\text { per tanaman }\end{array}$ & Bobot 100 biji & $\begin{array}{c}\text { Bobot biji } \\
\text { per tanaman }\end{array}$ & $\begin{array}{c}\text { Bobot biji } \\
\text { per baris }\end{array}$ \\
\hline BTN 1 & $15,20 \mathrm{c}$ & $30 \mathrm{~cm}$ & 9,027 & 2,69 & $53,81 \mathrm{c}$ \\
BTN 2 & $13,08 \mathrm{c}$ & $29,25 \mathrm{~cm}$ & 9,10 & 2,45 & 49,01 \\
BTN 5 & $16,05 \mathrm{c}$ & $33,87 \mathrm{~cm}$ & 9,72 & $2,93 \mathrm{c}$ & $58,55 \mathrm{c}$ \\
CK 0 & $20,08 \mathrm{~cm}$ & $39,80 \mathrm{~cm}$ & 9,21 & $3,47 \mathrm{c}$ & $69,31 \mathrm{~cm}$ \\
CK 15 & $17,60 \mathrm{~cm}$ & 34,90 & 7,52 & 2,63 & $52,61 \mathrm{c}$ \\
CK 5 & $13,33 \mathrm{c}$ & $29,17 \mathrm{~cm}$ & 9,44 & 2,28 & 45,64 \\
CK 6 & $17,00 \mathrm{~cm}$ & $33,00 \mathrm{~cm}$ & 8,94 & $3,08 \mathrm{c}$ & $61,65 \mathrm{c}$ \\
JT 3 & $20,33 \mathrm{~cm}$ & $42,30 \mathrm{~cm}$ & 8,38 & 2,55 & 51,09 \\
KA 6 & $20,83 \mathrm{~cm}$ & $38,75 \mathrm{~cm}$ & 9,16 & $3,25 \mathrm{c}$ & $65,09 \mathrm{~cm}$ \\
KA 7 & $19,30 \mathrm{~cm}$ & $39,00 \mathrm{~cm}$ & 9,18 & $3,51 \mathrm{c}$ & $70,18 \mathrm{~cm}$ \\
KBI 1 & $15,10 \mathrm{c}$ & $26,62 \mathrm{c}$ & 13,92 & $3,11 \mathrm{c}$ & $62,27 \mathrm{c}$ \\
KH 8 & $12,88 \mathrm{c}$ & $25,10 \mathrm{c}$ & 12,11 & 2,76 & $55,28 \mathrm{c}$ \\
SM 2 & $17,00 \mathrm{~cm}$ & $35,10 \mathrm{~cm}$ & 7,06 & 2,57 & 51,38 \\
Cikuray & 11,04 & 22,20 & 14,33 & 2,55 & 50,98 \\
Malika & 16,00 & 27,70 & 11,55 & 3,08 & 61,55 \\
\hline
\end{tabular}

Keterangan: $\mathrm{c}=$ lebih baik dari Cikuray; $\mathrm{m}$ = lebih baik dari Malika

Cekaman akibat tanaman jagung menyebabkan pembentukan biji kedelai terganggu. Tanaman jagung yang berhabitus lebih tinggi dengan sistem perakaran yang lebih rapat dari kedelai menjadi kompetitor yang kuat baik dalam pemanfaatan cahaya di atas permukaan tanah maupun penyerapan unsur hara dan air di bagian bawah permukaan tanah untuk proses fotosintesis (Turmudi, 2002). Hal tersebut menyebabkan proses fotosintesis tanaman tidak maksimal sehingga pembentukan biji menjadi terganggu.

Pada karakter bobot 100 biji ternyata hasil uji lanjut menunjukkan bahwa semua genotipe yang diuji tidak lebih baik dari kultivar Cikuray maupun Malika. Artinya kultivar Cikuray dan Malika memiliki ukuran biji yang lebih besar dibandingkan dengan 13 genotipe yang diuji. Intensitas cahaya rendah akibat cekaman dari jagung diduga berpengaruh terhadap proses pembentukan biji. Murty \& Sahu (1987) berpendapat bahwa intensitas cahaya yang rendah menyebabkan terganggunya sintesis protein dan rendahnya ketersediaan karbohidrat yang mengakibatkan tingginya kehampaan. Selain akibat cekaman yang dialami kedelai ukuran biji dipengaruhi oleh faktor genetik tanaman. Menurut Kamil (1986), tinggi rendahnya berat 100 biji tergantung dari banyak atau sedikitnya bahan kering yang terdapat di dalam biji, bentuk biji dan ukuran biji yang dipengaruhi oleh gen tanaman itu sendiri. Selain itu, berdasarkan deskripsi masingmasing kultivar cek, semua kultivar cek memiliki keunggulan pada karakter bobot 100 biji.

Karakter bobot 100 biji sangat berpengaruh terhadap karakter bobot biji per tanaman. Tabel 3 menunjukan bahwa hanya terdapat enam genotipe yang lebih unggul dibanding kultivar Cikuray, sementara tidak terdapat genotipe yang lebih unggul dibanding kultivar Malika. Selain pada karakter bobot biji per tanaman, karakter bobot 100 biji juga berpengaruh terhadap karakter bobot biji per baris. Hasil uji LSI menunjukkan hanya terdapat tiga genotipe yang lebih baik dibanding kedua kultivar cek yaitu genotipe CK 0, KA 6, dan KA 7.

Dalam kondisi tercekam intensitas cahaya, tanaman kedelai akan mengalami penurunkan karbohidrat hasil dari fotosintesis. Menurut Sopandie \& Trikoesoemaningtyas (2011), intensitas cahaya yang rendah menyebabkan rendahnya pembentukan 3-PGA yang menghambat kerja enzim ADP-glukosa pyrofosfatase karena adanya Pi yang berinteraksi dengan 3-PGA. Pada intensitas cahaya rendah terjadi gangguan translokasi karbohidrat, demikian juga gula total (sebagian besar gula nonreduksi dan pati) nyata menurun pada seluruh 
bagian tanaman. Tanaman yang tumbuh di lingkungan tercekaman dengan intensitas cahaya rendah sulit mengekspresikan kemampuan genetiknya secara penuh untuk tumbuh dan berproduksi dengan baik sehingga hasil kedelai menurun rata-rata $30-60 \%$ pada kondisi cekaman naungan (Sopandie \& Trikoesoemaningtyas, 2011). Walaupun demikian hasil penelitian ini menunjukkan bahwa terdapat genotipe-genotipe yang lebih unggul dibandingkan dengan kultivar Cikuray dan Malika pada beberapa karakter hasil.

\section{Simpulan}

\section{SIMPULAN DAN SARAN}

Genotipe-genotipe yang lebih unggul dibandingkan dengan kultivar Cikuray dan Malika adalah BTN 1, BTN 2, BTN 5, dan CK 5 pada karakter jumlah biji per tanaman dan genotipe CK 15 pada karakter jumlah polong per tanaman. Sementra itu, genotipe SM 2 pada karakter jumlah polong per tanaman dan jumlah biji per tanaman, genotipe CK 0, KA 6, dan KA 7 pada karakter jumlah polong per tanaman, jumlah biji per tanaman dan bobot biji per baris.

\section{Saran}

Genotipe CK 0, KA 6, dan KA 7 dapat direkomdasikan sebagai genotipe unggul untuk pertanaman tumpangsari pola 2:1 dengan jagung.

\section{UCAPAN TERIMA KASIH}

Ucapan terima kasih serta penghargaan yang setinggi-tingginya disampaikan kepada Direktorat Jenderal Pendidikan Tinggi Kementerian Pendidikan dan Kebudayaan yang telah menyediakan pendanaan Hibah Kompetitif Strategi Nasional Tahun 2015 sehingga penelitian ini memungkinkan untuk dilaksanakan.

\section{DAFTAR PUSTAKA}

Beets, WC. 1982. Multiple Cropping and Tropical Farming Systems. Gower Publishing Company Limited, England. 156 p.
Gasperz, V. 2006. Sistem Manajemen Kinerja Terintegrasi Balanced Scorecard dengan Six Sigma Organisasi dan Pemerintah. PT. Gramedia Pustaka Utama, Jakarta.

Gomez, KA and AA Gomez. 1995. Prosedur Statistik untuk Penelitian Pertanian. Terjemahan: E. Sjamsuddin dan J. S Baharsyah. Penerbit Universitas Indonesia, Jakarta.

Kamil, J. 1986. Teknologi Benih. Angkasaraya, Padang.

Murty, KS and G Sahu. 1987. Impact of low-light stress on growth and yield of rice. Pp. 94100 in Weather and Rice. Proc. International Workshop on Impact of Weather Parameters on Growth and Yield of Rice. IRRI. Los Banos. 7-10 April 1986.

Petersen, RG. 1994. Agricultural Field Experiments: Design and Analysis. Marcel Dekker, New York.

Rachmadi, M. 2002. Analisis Seleksi dan Respon Genotipe-genotipe Kedelai pada Lingkungan Pertanaman Tumpangsari Kedelai dengan Jagung. Disertasi Program Pascasarjana. Universitas Padjadjaran. Tidak dipublikasikan.

Rifai, A, S Basuki, dan B Utomo. 2014. Nilai kesetaraan lahan budi daya tumpang sari tanaman tebu dengan kedelai: Studi kasus di Desa Karangharjo, Kecamatan Sulang, Kabupaten Rembang. Jurnal Widyariset. 17 (1): 59-70.

Singh, RK and BD Chaudhary. 1977. Biometrical Methods in Quantitative Genetic Analysis. Kalyani Publishers, New Delhi.

Sopandie, D dan Trikoesoemaningtyas. 2011. Pengembangan tanaman sela di bawah tegakan tanaman tahunan. Iptek Tanaman Pangan 6 (2): 168-182.

Turmudi, E. 2002. Kajian pertumbuhan dan hasil tanaman dalam sistem tumpangsari jagung dengan empat kultivar kedelai pada berbagai waktu tanam. Jurnal Ilmu-ilmu Pertanian Indonesia. 4 (2): 89-96. 